\title{
Tuberculin skin testing in HIV-infected patients in Campo Grande, Mato Grosso do Sul State, Brazil
}

De Oliveira SMVL (1), Paniago AMM (2), Bonecini-Almeida MG (3), Bertoni N (4), Stabile AC (5), Da Cunha RV (2), De Oliveira OA (6), Druzian AF (1), Negri AC (7), Andreotti R (8)

(1) Graduate Program in Infectious and Parasitic Diseases, Federal University of Mato Grosso do Sul, Campo Grande, Mato Grosso do Sul State, Brazil; (2) Medical School, Federal University of Mato Grosso do Sul, Campo Grande, Mato Grosso do Sul State, Brazil; (3) Laboratory of Immunology and Immunogenetics, Evandro Chagas Institute of Clinical Research, Oswaldo Cruz Foundation, FIOCRUZ, Rio de Janeiro, Rio de Janeiro State, Brazil; (4) Laboratory of Information in Health, Institute for Scientific and Technological Communication and Information in Health, Oswaldo Cruz Foundation, FIOCRUZ, Rio de Janeiro, Rio de Janeiro State, Brazil; (5) Introductory Science Program, Anhanguera Education Center-UNIDERP, Campo Grande, Mato Grosso do Sul State, Brazil; (6) Department of Nursery, Federal University of Mato Grosso do Sul, Campo Grande, Mato Grosso do Sul State, Brazil; (7) Federal University of Mato Grosso do Sul, Campo Grande, Mato Grosso do Sul State, Brazil; (8) Embrapa Beef Cattle, Campo Grande, Mato Grosso do Sul State, Brazil.

ABSTRACT: A cross-sectional study on HIVIAIDS was carried out in 108 outpatients from the university hospital of the Federal University of Mato Grosso do Sul, Campo Grande, Brazil, from July to December 2008, to investigate latent tuberculosis infection using the tuberculin skin test (TST). The prevalence of positive results was $13.9 \%$. The CD4+ T cell count $(p=0.091)$ and the diagnosis time $(p=0.010)$ were statistically significant when compared with TST positivity. In the cohort of HIVIAIDS patients who had latent tuberculosis infection, the median diagnosis time was eight years. Undetectable viral load presented significant association $(p=0.046)$ with tuberculosis infection. The fact that numerous individuals with HIVIAIDS infection presented a negative reaction to the tuberculin skin test is probably related to alterations in the cellular immune response induced by HIV infection. The tuberculin test is a useful tool for the detection of latent tuberculosis infection and should be performed in all HIVIAIDS individuals at the time of the diagnosis and on a yearly basis, if negative. Both the early identification of the tuberculosis infection by the tuberculin skin test at the moment of immunological restoration and chemoprophylaxis in infected individuals are mechanisms to control HIVIAIDS and tuberculosis coinfection.

KEY WORDS: tuberculin skin test, acquired immunodeficiency syndrome, CD4/CD8 cell count.

CONFLICTS OF INTEREST: There is no conflict

FINANCIAL SOURCE: Anhanguera Education Center and University for the Development of the State and the Pantanal Region (UNIDERP).

\section{CORRESPONDENCE TO:}

SANDRA MARIA DO VALLE LEONE DE OLIVEIRA, Hospital Dia Profa. Esterina Corsini, Universidade Federal de Mato Grosso do Sul, Rua Fillinto Muller, s/n, Vila Ipiranga, Cidade Universitária, Campo Grande, MS, 79.080-190, Brasil. Phone: +55 6733453651 or +55 67 3042 8725. Email: sandrinhaleone@gmail.com. 


\section{INTRODUCTION}

In 2006, the World Health Organization reported approximately 9.2 million cases of active tuberculosis with 1.7 million deaths worldwide per year. Among the 85,000 cases of tuberculosis currently reported to the surveillance system in Brazil, nearly $8 \%$ are coinfected with human immunodeficiency virus (HIV) (1-3). In Brazil, an average of 600,000 individuals is presently infected with HIV, which comprises one of the main risk factors for the progression from a latent tuberculosis infection to the active disease $(1,4-7)$.

Persons recently infected with Mycobacterium tuberculosis have a 3 to $5 \%$ chance to develop the disease in the first two years and 5 to $15 \%$ during their lifetime (8). Most infected people remain healthy with a latent infection, demanding several immune mechanisms to prevent the disease progression $(3,9,10)$. Tuberculosis cases result from the evolution of a latent reactivated focus or from a recent exogenous infection. Latent infection affects one third of the world population and the possibility of a latent reactivation focus in HIV-infected people, without intervention, may reach $10 \%$ every year $(11,12)$. Tuberculosis lies among the major causes of opportunistic diseases in HIV-infected patients, leading to high lethality $(1,4,9,13)$.

The identification of latent tuberculosis infection makes possible the adoption of strategies to lower its morbidity and mortality rates in HIVIAIDS patients (4, 13-16). Even presenting limitations, the tuberculin skin test (TST) is the most commonly used infection-detection method and should be performed in all HIV-infected individuals at the time of diagnosis and annually, if the first result is negative (16). In asymptomatic HIV-positive patients an induration equal to or greater than $5 \mathrm{~mm}$ is a positive result $(6,8,17)$. After a positive diagnosis, the patients should receive isoniazid chemoprophylaxis. The risk of reactivation of latent tuberculosis is believed to increase up to 100-fold when compared with HIV negative individuals, whereas the development of the active disease in the HIVIAIDS population may have an incidence of 1.7 to 7.9 per 100 persons per year $(15,18)$.

The objective of the present study was to investigate latent tuberculosis infection using the tuberculin skin test (TST) in patients assisted at the university hospital in Campo Grande, Mato Grosso do Sul, Brazil, to compose the latent tuberculosis scenario in the midwest of Brazil. 


\section{PATIENTS AND METHODS}

\section{Patients}

This is a cross-section descriptive study with quantitative approach. The HIVIAIDS population was selected from the Day-Care Hospital Prof. Esterina Corsini, at the Federal University of Mato Grosso do Sul (UFMS), Campo Grande, Brazil, in 2008.

The sample size was calculated considering the prevalence of tuberculosis infection estimated in $15 \%( \pm 6 \%)$, based on studies carried out with the HIVIAIDS population; significance level 5\% (19-20). Thus, the minimal sample size to meet the aim of this study was 108 adult patients, a non-probabilistic sample of HIVIAIDS patients treated during June through December, 2008.

\section{Ethical Aspects}

The project was approved by the Ethical Committee of UFMS (protocol 1060). All volunteers signed a document of informed consent.

\section{Data Collection}

All participants were asked to answer a questionnaire on sociodemographic variables (age, gender and formal education level), childhood BCG (bacille Calmette-Guèrin) vaccination and social habits (alcohol and tobacco consumption). Information about the period of HIVIAIDS diagnosis and highly active antiretroviral treatment (HAART) was provided by medical records. Since CD4+ T and CD8+ T cell counts and HIV load are routinely performed as part of the clinical follow-up of all HIVIAIDS patients in Brazil, those results were obtained from the medical records, as close as possible to the TST time. The viral load test was performed by the Central Public Health Laboratory in Campo Grande, MS, using a b-DNA technique (Versant HIV-1 RNA 3.0 Assay ${ }^{\circledR}$, Siemens, USA) with the detection level ranging from 50 to 500,000 copies $/ \mathrm{mL}$. The tuberculin skin test utilized a 2 UT $(0.04 \mu \mathrm{g})$ purified protein derivative, (PPD), RT 23 (recent tuberculin), from the Statens Serum Institut (Denmark). An amount of $0.1 \mathrm{~mL}$ of this PPD is equivalent to 5 UT of other PPD-S used in some countries. The PPD was provided by the Hélio Fraga Filho Reference Center of the Brazilian Ministry of Health. A 0.1-mL dose of PPD was subcutaneously injected into the anterior side of the left forearm, forming a papule with well-defined borders (8). The induration was measured after 48 to 72 hours and results of at least $5 \mathrm{~mm}$ were considered positive. 


\section{Statistical Analysis}

Chi-square $\left(X^{2}\right)$ test was employed to evaluate the relation between latent tuberculosis infection and sociodemographic and clinical variables. Continuous variables (CD4+ T /CD8 +T cell counts and viral load) were examined by the median test. Stata ${ }^{\circledR}$ version 9 software (StataCorp LP, USA) was used for the statistical analysis.

\section{RESULTS}

Of the 492 HIVIAIDS patients clinically followed at the Day-Care Hospital Prof. Esterina Corsini, 108 were consecutively included from June to December 2008. Among the studied individuals, $53.70 \%$ (58) were females; $76.85 \%$ (83) were aged between 20 and 49 years, and in $62.96 \%$ (66) the formal education level ranged from 0 to 10 years of schooling.

Latent tuberculosis infection was identified in $13.9 \%$ of the HIVIAIDS patients, of whom $66.76 \%$ (10) were female and $73.3 \%$ were aged between 20 and 49 years. There was no statistical difference between the TST-positive HIVIAIDS patients and the TST-negative persons regarding sex, age, schooling, familiar income, smoking habit and alcohol abuse (screened through the CAGE questionnaire) as shown in Table 1. 
De Oliveira SMVL et al. Tuberculin skin testing in HIV-infected patients in Campo Grande, Mato Grosso do Sul State, Brazil. J Venom Anim Toxins incl Trop Dis. 2010;16(2):289

Table 1. Sociodemographic characteristics and results of the tuberculin skin test of HIVIAIDS patients in Campo Grande, Mato Grosso do Sul state, Brazil, 2008

\begin{tabular}{|c|c|c|c|c|c|c|c|c|}
\hline \multirow{3}{*}{$\begin{array}{l}\text { Sociodemographic } \\
\text { characteristics }\end{array}$} & \multicolumn{6}{|c|}{ Tuberculin skin test } & \multirow{3}{*}{ p-value* } & \multirow{3}{*}{$\begin{array}{c}\text { OR (95\% } \\
\quad \text { Cl) }\end{array}$} \\
\hline & \multicolumn{2}{|c|}{ Positive } & \multicolumn{2}{|c|}{ Negative } & \multicolumn{2}{|c|}{ Total } & & \\
\hline & $\mathrm{n}$ & $\%$ & $\mathrm{n}$ & $\%$ & $\mathrm{n}$ & $\%$ & & \\
\hline \multicolumn{9}{|l|}{ Gender } \\
\hline Male & 5 & 33.33 & 45 & 48.39 & 50 & 46.30 & \multirow[b]{2}{*}{0.278} & 1.000 \\
\hline Female & 10 & 66.67 & 48 & 51.61 & 58 & 53.70 & & $\begin{array}{l}1.875 \\
(0.588- \\
5.979)\end{array}$ \\
\hline \multicolumn{9}{|l|}{ Age group (years) } \\
\hline 20 to 49 & 11 & 73.33 & 72 & 77.42 & 83 & 76.85 & \multirow[b]{2}{*}{$0.746^{a}$} & 1.000 \\
\hline 50 or more & 4 & 26.67 & 21 & 22.58 & 25 & 23.15 & & $\begin{array}{c}1.247 \\
(0.357- \\
4.351)\end{array}$ \\
\hline \multicolumn{9}{|l|}{ Schooling (years) } \\
\hline 0 to 6 & 6 & 40.00 & 34 & 36.56 & 40 & 37.04 & \multirow[b]{2}{*}{0.798} & 1.000 \\
\hline 7 or more & 9 & 60.00 & 59 & 63.44 & 68 & 62.96 & & $\begin{array}{c}1.400 \\
(0.368- \\
5.328)\end{array}$ \\
\hline \multicolumn{9}{|l|}{ Smoking } \\
\hline Never smoked & 5 & 33.33 & 40 & 43.01 & 45 & 41.67 & \multirow[b]{2}{*}{0.481} & 1.000 \\
\hline Smoker/ex-smoker & 10 & 66.67 & 53 & 56.99 & 63 & 58.33 & & $\begin{array}{c}1.509 \\
(0.474- \\
4.802)\end{array}$ \\
\hline \multicolumn{9}{|l|}{ CAGE } \\
\hline No & 10 & 83.33 & 48 & 82.76 & 58 & 82.86 & \multirow[b]{2}{*}{$0.999^{a}$} & 1.000 \\
\hline Yes & 2 & 16.67 & 10 & 17.24 & 12 & 17.14 & & $\begin{array}{c}0.960 \\
(0.180- \\
5.131)\end{array}$ \\
\hline \multirow{3}{*}{ Per capita income (in $\mathrm{R} \$$ ) } & \multicolumn{4}{|c|}{ Positive } & \multicolumn{3}{|c|}{ Negative } & \multirow{2}{*}{$p$-value** } \\
\hline & $\mathrm{n}$ & Median & & IQR & $\mathrm{n}$ & Median & IQR 200; & \\
\hline & 15 & 400 & & $0 ; 750$ & 89 & 333 & 500 & 0.402 \\
\hline
\end{tabular}

* Pearson's chi-square test ('Fisher's exact test was used when the sample size was less than five).

** Median test.

Note: CAGE is an acronym for "Cut-down, Annoyed by criticism, Guilty and Eye-opener" questionnaire.

The scar of BCG vaccination in childhood did not show statistical difference among TST-positive patients. Information about CD4+ T and CD8+ T cell counts was collected from all patients through their clinical records. In relation to other clinical 
variables, CD4+ T cell count was significantly associated, at 10\% level, with positive tuberculin test. In the negative tuberculin reaction group, the median value of CD4+ T cells was 390 cells $/ \mathrm{mm}^{3}$, whereas in the TST positive group this count (average) was 626 cells $/ \mathrm{mm}^{3}$ ( $p$-value $\left.=0.091\right)$. It was also observed that among persons who reacted negatively, the median value of CD8+ $T$ was higher than among those with positive TST $(p$-value $=0.026$ ) and about twice as high as CD4+ T in the same group (Table 2).

The diagnosis time showed to be considerably associated with TST positivity ( $p$ value $=0.01$, with a median diagnosis time of eight years, whereas among TSTnegative patients, this period was four years (Table 2).

The group of TST positive individuals in use of antiretroviral therapy did not present any statistical difference. Eighty-two and 41\% HIVIAIDS patients were under highly active antiretroviral treatment.

The viral load revealed a significant association ( $p$-value $=0.046$ ) when compared with the TST-positivity variable. A higher level of viral load was observed in TSTnegative individuals. In those who reacted positively, $80 \%(12 / 15)$ had undetectable viral RNA load (log $\leq 50$ copies $/ \mathrm{mL}$ ), as displayed in Table 2, represented by the value 49. 
Table 2. Clinical characteristics and tuberculin skin test among HIVIAIDS patients in Campo Grande, Mato Grosso do Sul state, Brazil, 2008

\begin{tabular}{|c|c|c|c|c|c|c|c|c|}
\hline \multirow{3}{*}{$\begin{array}{c}\text { Clinical } \\
\text { characteristics }\end{array}$} & \multicolumn{6}{|c|}{ Tuberculin skin test } & \multirow{3}{*}{ p-value* } & \multirow{3}{*}{ Odds ratio (OR) } \\
\hline & \multicolumn{2}{|c|}{ Positive } & \multicolumn{2}{|c|}{ Negative } & \multicolumn{2}{|r|}{ Total } & & \\
\hline & $\mathrm{n}$ & $\%$ & $\mathrm{n}$ & $\%$ & $\mathrm{n}$ & $\%$ & & \\
\hline \multicolumn{7}{|l|}{ BCG scar } & \multirow{3}{*}{0.512} & \\
\hline Yes & 9 & 60.00 & 59 & 68.60 & 68 & 67.33 & & $\begin{array}{c}0.686(0.220- \\
2.140)\end{array}$ \\
\hline No & 6 & 40.00 & 27 & 31.40 & 33 & 32.67 & & 1.000 \\
\hline \multicolumn{9}{|l|}{ HAART } \\
\hline Yes & 13 & 86.67 & 76 & 81.72 & 89 & 82.41 & \multirow{2}{*}{$0.999^{a}$} & $\begin{array}{c}1.454(0.297- \\
7.114)\end{array}$ \\
\hline \multirow[t]{2}{*}{ No } & 2 & 13.33 & 17 & 18.28 & 19 & 17.59 & & 1.000 \\
\hline & \multicolumn{4}{|c|}{ Positive } & \multicolumn{3}{|c|}{ Negative } & \\
\hline \multirow[t]{2}{*}{ CD4+ T cell count } & $\mathrm{n}$ & Median & & QR & $\mathrm{n}$ & Median & IQR & \\
\hline & 15 & 626 & & 8; 977 & 93 & 390 & $251 ; 627.5$ & 0.091 \\
\hline CD8+ T cell count & 15 & 763 & & $6 ; 961$ & 93 & 985 & $676.5 ; 1227.5$ & 0.026 \\
\hline Viral load & 15 & 49 & & $9 ; 49$ & 93 & 118 & $49 ; 9757.5$ & 0.046 \\
\hline $\begin{array}{l}\text { Diagnosis time } \\
\text { (years) }\end{array}$ & 15 & 8 & & $5 ; 11$ & 92 & 4 & $1 ; 7$ & 0.01 \\
\hline
\end{tabular}

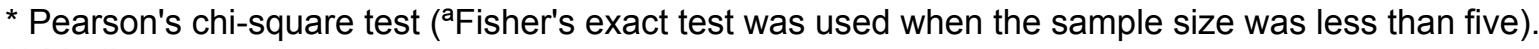

${ }^{* *}$ Median test.

\section{DISCUSSION}

The prevalence of tuberculosis infection in Latin America is well documented and affects about $30 \%$ of the general population (13). In Europe and North America, although the prevalence of tuberculosis is lower, the reemergence of this disease has been well described, due to HIVIAIDS pandemics afflicting especially immigrants from Latin American countries and vulnerable populations (refugees, healthcare professionals, inmates and drugs addicts), who are more exposed to tuberculosis infection and disease $(4,21-25)$. Brazilian studies indicate a 20 to $50 \%$ prevalence of tuberculosis infection in susceptible persons such as healthcare professionals (25).

The increase of tuberculosis and HIVIAIDS coinfection rates has given rise to serious implications for tuberculosis control programs due to the augmentation of cases and 
elevated mortality rates in the coinfected population $(13,24)$. Several studies carried out in Latin American countries demonstrated that tuberculosis infection rates in HIVIAIDS population range from 0 to $25 \%(15,20,22,26,27)$. The present study found a $13.9 \%$ prevalence of tuberculosis infection in the HIVIAIDS population.

The connection between the number of lymphocytes CD4+ T per cubic millimeter and the skin response to PPD remains unclear in the literature $(16,28)$. In the current study, no significant association between tuberculin positive individuals and CD4+T lymphocyte count was found. In the population who tested negative for tuberculin, the median value of CD4+ $T$ cells showed to be significantly lower, as previously reported by other researchers $(16,20)$.

Several studies reported that most HIV-infected individuals do not respond to the skin test with PPD, thus showing a statistical relation with a low CD4+T cell count (20). On the other hand, other works did not find any connection between TST positivity and induration higher than $5 \mathrm{~mm}$ or higher absolute counting of CD4+T cells (16). Moreover, anergy is soundly related to low CD4+T cell count (20). Some authors found 10 to $80 \%$ anergy in HIVIAIDS populations $(20,26)$.

In the current study, it is worth noting that any participant with positive tuberculin test had CD4+T cell count lower than $200 / \mathrm{mm}^{3}$. In the literature, low CD4+T cell count is associated with negative tuberculin test $(20,26,27)$.

The prevalence of tuberculosis infection in the group of patients with CD4+T count equal to or greater than 350 cells $/ \mathrm{mm}^{3}$ appears to be closest to reality, as individuals with $\mathrm{CD} 4+\mathrm{T}$ count equal to or less than $350 / \mathrm{mm}^{3}$ may have presented negative tuberculin test due to anergy (16).

Likewise, the median value of CD8+ T was about twice greater than that of CD4+T in the group of negative individuals. CD4+ $T$ and the components of this cell population in the lung, when infected by HIV, have their cellular activities damaged, increasing the vulnerability to opportunistic infections such as tuberculosis. CD8+T cells participate in the immune response against tuberculosis bacillus and animal models demonstrate the susceptibility to $M$. tuberculosis infection in this cell subpopulation. These cells are involved in the activation of macrophages and are sources of $\gamma$ interferon and cytokines (20).

The viral load comprises an important clinical marker in the progression of HIV and, in this study, showed to be associated with tuberculosis infection. The group of TST positive individuals had undetectable viral load (cutoff at 50 HIV-1 RNA copies $/ \mathrm{mL}$ ). 
Elevated viral replication and increased viral load are known to be associated with accelerated deterioration of the immune system and drop of CD4+ T cell count (24). Likewise, a longer diagnosis time may be associated with TST positivity due to extended periods of clinical follow-up and monitoring. Probably, the use of antiretroviral drugs in these patients reestablishes the preexisting hypersensitivity to the immunological memory to tuberculosis. This means that undetected individuals or those who previously tested negative for TST, in the absence of a new infection, present immunological recall to a preexisting TB hypersensitivity.

Antiretroviral therapy is an important tool in the control of latent tuberculosis infection. Clinical and therapeutic follow-up of HIVIAIDS individuals provides protection factors against the development of tuberculosis, which are described as one of main determinants of recovery and an indicator of survival, reduction of hospitalalization, improvement in the quality of life and decrease of latent infections (15, 22, 28-30). However, monitoring alone is not sufficient for the tuberculosis control; thus, isoniazid preventive therapy is highly recommended $(15,18)$.

Since numerous patients affected by HIVIAIDS infection were non-reactive to TST, probably due to alterations in cellular immune response caused by the virus, it is possible that, during the investigation of the booster phenomenon, an increase in the identification rate of infected individuals is noticed $(8,23,31,32)$.

Boosting of TST comprises a retesting in the absence of a new infection, an immunological recall of preexisting hypersensitivity to tuberculosis (33). In order to evaluate the booster phenomenon, all negative patients were invited to repeat the TST after a period of one to three weeks. The occurrence of the booster phenomenon was identified when the first TST showed an induration smaller than 10 $\mathrm{mm}$ and the second TST presented an increase greater than $6 \mathrm{~mm}$ when compared with the first evaluation, with an induration of at least $10 \mathrm{~mm}(8)$.

Tuberculin test is a useful method in the detection of tuberculosis infection and should be performed in all HIVIAIDS patients at the time of diagnosis and annually if they present negative response. In the first test, the evaluation of the booster effect may be useful.

The early identification of tuberculosis infection by TST at the moment of immunological restoration in addition to the management of chemoprophylaxis in infected individuals comprise effective means for controlling the interaction between HIVIAIDS and tuberculosis. Other alternatives, including the investigation of booster 
phenomenon and techniques such as interferon release assays (in vitro) are possibilities that may be further investigated in the diagnosis of latent infection (16). Healthcare services must overcome the operational difficulties and offer yearly tracing to these individuals.

\section{ACKNOWLEDGMENTS}

The authors would like to thank the Central Public Health Laboratory in Campo Grande, the Day-Care Hospital Prof. Esterina Corsini (UFMS) and the Anhanguera Education Center staff for supporting this study.

\section{REFERENCES}

1. Saraceni V, King BS, Cavalcante SC, Golub JE, Lauria LM, Moulton LH, et al. Tuberculosis as primary cause of death among AIDS cases in Rio de Janeiro, Brazil. Int J Tuberc Lung Dis. 2008;12(7):769-72.

2. The World TB day. The International Union against tuberculosis and lung disease [Internet]. Chicago: The Association. The world TB day. Press release; 2009. [updated 2001 Aug 23; cited 2010 Jul 01] Available from: http: www.stoptb.org/events/worldtbday/2009.

3. Young DB, Gideon HP, Wilkinson RJ. Eliminating latent tuberculosis. Trends Microbiol. 2009;17(5):183-8.

4. Dias-Baptista IMF, Usó S, Marcondes-Machado J. Trends in multidrug-resistant tuberculosis. J Venom Anim Toxins incl Trop Dis. 2008;14(2):203-23.

5. Inselman L. Tuberculin skin testing and interpretation in children. Pediatr Asthma Allergy Immunol. 2003;16(4):225-35.

6. Richeldi L. An update on the diagnosis of tuberculosis infection. Am J Respir Crit Care Med. 2006;174(6):736- 42.

7. Ruffino-Netto A. Evaluation of the excess of cases of tuberculosis due to HIVIAIDS infection: a preliminary assay. Rev Saúde Públ. 1995;29(4):279-82.

8. Kritski AL, Conde MB, Souza GRM, Pedra AM, Trope BM, André C, et al. Infecção latente pelo Mycobacterium tuberculosis. In: Kristki AL, Conde MB, Souza GRM, Pedra AM, Trope BM, André C, et al, editors. Tuberculose: do ambulatório à enfermaria. 4th ed. Rio de Janeiro: Atheneu; 2008. p. 181-95. 
9. de Pinho AM, Santoro-Lopes G, Harrison LH, Schechter M. Chemoprophylaxis for tuberculosis and survival of HIV-infected patients in Brazil. AIDS. 2001;15(16):212935.

10. Jonhson JL, Okwera A, Hom D, Mayanja H, Mutuluuza Kityo C, et al. Duration of efficacy of treatment of latent tuberculosis infection in HIV-infected adults. AIDS. 2001;15(16):2137-47.

11. Orme M. The latent tuberculosis bacillus (l'll let you know if I ever meet one). Int J Tuberc Lung Dis. 2001;5(7):589-93.

12. Horsburgh CR Jr. Priorities for the treatment of latent tuberculosis infection in the United States. N Engl J Med. 2004;350(20):2060-7.

13. Jamal LF, Moherdaui F. Tuberculosis and HIV infection in Brazil: magnitude of the problem and strategies for control. Rev Saúde Públ. 2007;41(Suppl 1):104-10.

14. Pineda NIS, Pereira SM, Matos ED, Barreto ML. Quimioprofilaxia na prevenção da tuberculose. J Bras Pneumol. 2004;30(4):485- 94.

15. Golub JE, Saraceni V, Cavalcante SC, Pacheco AG, Moulton LH, King BS, et al. The impact of antiretroviral therapy and isoniazid preventive therapy on tuberculosis incidence in HIV-infected patients in Rio de Janeiro, Brazil. AIDS. 2007;21(11):14418.

16. Reid MJ, Shah NS. Approaches to tuberculosis screening and diagnosis in people with HIV in resource-limited settings. Lancet Infect Dis. 2009;9(3):173-84.

17. Cesar MC, Melo DA, Xavier GM, Salles C, Ruffino-Netto A. Prova tuberculínica cutânea. Pulmão RJ. 2003;12(3):116-27.

18. Chaisson RE, Martinson N. Tuberculosis in Africa: combating an HIV-driven crisis. N Engl J Med. 2008;358(11):1089-92.

19. de Souza L do R, Galvão MT, Machado JM, Meira DA, Cunha K. Tuberculin testing of individuals infected with the human immunodeficiency virus: relationship with peripheral T-cell counts and active tuberculosis. J Bras Pneumol. 2006;32(5):438-43

20. Rodriguez JL, Arias M, Paris SC, Arbeláez MP, Betancur J, Garcia LF. Tuberculin skin test and CD4+/CD8+ T-cell counts in adults infected with the human immunodeficiency virus in Medellin, Colombia. Mem Inst Oswaldo Cruz. 1997;92(2):245-50. 
21. de Oliveira SM, Honner MR, Paniago AM, Aguiar ES, Venâncio da Cunha R. Prevalence of Mycobacterium tuberculosis among professionals in a university hospital, Mato Grosso do Sul, 2004. Rev Lat Am Enfermagem. 2007;15(6):1120-4.

22. Silveira JM, Sassi RA, de Oliveira Netto IC, Hetzel JL. Prevalence of and factors related to tuberculosis in seropositive human immunodeficiency virus patients at a reference center for treatment of human immunodeficiency virus in the southern region of the state of Rio Grande do Sul, Brazil. J Bras Pneumol. 2006;32(1):48-55.

23. Choudhary M, Ramirez L, Long $R$, Simmons KB, Blair DC, Forbes BA, et al. A university hospital's 10-year experience with tuberculin testing: value of the 2-step tuberculin skin test. Am J Infect Control. 2006;34(6):358-61.

24. Nunes EA, Capitani EM, Coelho E, Panunto AC, Joaquim OA, Ramos MC. Mycobacterium tuberculosis and nontuberculous mycobacterial isolates among patients with recent HIV infection in Mozambique. J Bras Pneumol. 2008;34(1):822-8. 25. Ostrosky Zeichner L, Rangel Fausto MS, García Romero E, Vázquez A, Ibarra MJ, Ponce de León Rozales S. Tuberculosis in healthcare workers: importance of surveillance and control programs. Salud Publica Mex. 2000;42(1):48-52.

26. Janis EM, Allen DW, Gjesby MJ, Carey LA, Mundy LM, Gopalan R, et al. Tuberculin skin test reactivity, anergy, and HIV infection in hospitalized patients. Longcope Firm of the Osler Medical. Am J Med. 1996;100(2):186-92.

27. Marks SM, Murrill C, Sanchez T, Liu KL, Finlayson T, Guilin V. Self-reported tuberculosis disease and tuberculin skin testing in the New York City House Ballroom community. Am J Public Health. 2008;98(6):1068-73.

28. Hosein S. Testing: skin tests on HIV-infected and non-HIV-infected people. TreatmentUpdate 59. 1995;7(5).

29. Nunes AA, Silva-Vergara ML, Melo IM, Silva ALA, Rezende LSA, Guimarães PB. Clinical and epidemiologic profile of hospitalized patients with HIV/Aids. Rev Panam Infectol. 2008;10(3):26-31.

30. Soares EC, Saraceni V, Lauria L de M, Pacheco AG, Durovni B, Cavalcante SC. Tuberculosis as a disease defining acquired immunodeficiency syndrome: ten years of surveillance in Rio de Janeiro, Brazil. J Bras Pneumol. 2006;32(5):444-8.

31. Leone de Oliveira SMV, Honer MR, Paniago AMM, Aguiar ES, Cunha RV. Booster effect on tuberculin skin tests at a university hospital in Mato Grosso do Sul. Rev Bras Saúde Ocup. 2008;33(117):72-6. 
De Oliveira SMVL et al. Tuberculin skin testing in HIV-infected patients in Campo Grande, Mato Grosso do Sul State, Brazil. J Venom Anim Toxins incl Trop Dis. 2010;16(2):297

32. Melo DA, Cezar MC, Xavier GM, Salles C. Booster phenomenon during evaluation of tuberculin skin test. Pulmão RJ. 2003;12(3):128-30.

33. Pai M, O'Brien R. Serial testing for tuberculosis: can we make sense of $T$ cell assay conversions and reversions? PLoS Med. 2007;4(6):e208. 